\title{
Jarosław Wołkonowski
}

Katedra Nauk Historyczno-Prawnych, Wydział Prawa

Uniwersytet w Białymstoku

\section{POLSKA I LITWA NA TLE STANDARDÓW MIEDZYNARODOWEJ OCHRONY MNIEJSZOŚCI NARODOWYCH I ETNICZNYCH W EUROPIE}

\section{Wstęp}

Obecna Europa liczy około pięćdziesięciu państw narodowych. Kontynent ten w swej bogatej historii nigdy nie miał tak dużo krajów na swym terenie. Powstały one z etnosów, które przeszły długą skomplikowaną drogę od zwykłych plemion do współczesnych narodów i zbudowały własne państwa narodowe. Europejscy politycy są dalecy od myśli na temat korekty granic. Tym niemniej rozpad Związku Sowieckiego i Jugosławii spowodował pojawienie się ponad dwudziestu nowych państw, które wcześniej były republikami związkowymi. Oprócz tego trzeba odnotować połączenie się dwóch krajów niemieckich, rozpad Czechosłowacji oraz uzyskanie niepodległości przez Kosowo. Wszystko to istotnie zmieniło przebieg granic w Europie. Wiele wskazuje na to, że dzisiejsza mapa tego kontynentu nie jest jeszcze ostateczna, gdyż część etnosów jest na drodze samostanowienia i tworzenia własnych państw narodowych. Dzisiaj znajdują się one na terenie innych krajów i tworzą tam mniejszości etniczne lub narodowe. Od dzisiejszej Europy zależy ich los - czy pójdą dalej swoją drogą w kierunku zbudowania państwa narodowego, czy zostaną poddane asymilacji i pragmatycznie wybiorą dostosowawczy model swego dalszego rozwoju.

Nie było i nie ma sposobu, by podzielić terytorium europejskie tak, aby wszystkie narody znalazły się w granicach swoich państw narodowych. Pewna część każdego narodu mieszka poza swym macierzystym krajem, to znaczy jest mniejszością narodową w innym państwie narodowym. Obcy element (kulturowo, mentalnie, politycznie) w państwie narodowym jest dla niego znaczącym problemem. Jego sedno to prawa mniejszości narodowych i etnicznych w Europie będące jednym z dylematów współczesnej polityki. Niemożliwość podziału terenu według kryterium narodowościowego, migracja imigrantów i uchodźców oraz swobodne przepływy ludności wywołują dużą różnorodność kulturową i etniczną, co według niektórych badaczy zagraża stabilności i spójności państw narodo- 
wych. Ale czy spójność oraz stabilność kraju rzeczywiście wymaga homogeniczności? Czy mogą być one zachowane mimo obecności różnych grup mniejszości narodowych i etnicznych w danym państwie? Celem niniejszego opracowania jest poszukiwanie odpowiedzi na postawione pytania.

\section{Sedno problemu mniejszości narodowych i etnicznych}

Każdy naród (grupa większościowa) po zbudowaniu swego państwa narodowego dąży do całkowitej dominacji na wszystkich płaszczyznach cywilizacyjnego rozwoju. Zaczyna się od dominacji polityczno-narodowej, terytorialnej, następnie gospodarczej, a w dalszej kolejności - zawodowej oraz kulturowej. Te dążenia etnosu są rzeczą naturalną wpisaną w ruch narodowy. Jest to wyraźnie widoczne szczególnie na początku samostanowienia - w pierwszym okresie budowania państwa narodowego. Dochodzi tutaj do konfrontacji pomiędzy dominacją (polityczno-narodową) jednego etnosu i mniejszością narodową lub etniczną w tym nowo powstającym państwie. Jej wynikiem ze strony większości narodowej jest próba zasymilowania mniejszości narodowych i etnicznych tego kraju. Jeżeli mniejszość narodowa lub etniczna jest prężna i dobrze zorganizowana, to działania większości narodowej idące w kierunku asymilacji wywołują opór z jej strony, co prowadzi do powstawania napięć i przesileń w samym państwie oraz - w dalszej kolejności - na kontynencie europejskim. Może dojść do ekscesów, incydentów, pogromów ${ }^{1}$, przesiedleń, wzrostu napięć i nienawiści na tle narodowościowym, a nawet do czystek etnicznych ${ }^{2}$.

W niektórych sytuacjach, rozpatrując relacje większość narodowa - mniejszość narodowa lub etniczna, można zbudować pewien model wspólistnienia między większością a mniejszością, aczkolwiek jest to zadanie trudne, wymagające określonej kultury politycznej, poziomu wykształcenia oraz tolerancji z obu stron. O wiele częściej większość narodowa stosuje rozwiązania oparte na wrogości i izolacji mniejszości. Takie podejście powoduje napięcia, generuje stereotypy, dyskryminację, a może nawet doprowadzić do pogromów i czystek etnicznych.

${ }^{1}$ Pogrom (z ros. zniszczenie) - termin odnosi się do grupowych napaści grupy większościowej na mniejszościową. Miały miejsce wobec Żydów, Romów, Szyitów, Ormian i innych. W potocznym rozumieniu określenie to stosuje się do aktów przemocy wobec Żydów. W pogromie możemy wydzielić dwie fazy: pierwsza to narastanie napięcia między ludźmi z różnych przyczyn i druga faza to najczęściej spontaniczny, lawinowy wylew nienawiści i złości ludzkiej w postaci grupowych aktów przemocy.

${ }^{2}$ Czystki etniczne to siłowe i fizyczne usunięcie osób określonej grupy etnicznej z pewnego terenu. Stosowane jest często w czasie wojny, w systemach totalitarnych i w systemach politycznych państw, gdzie są łamane zasady demokracji. Może mieć charakter jawny (wywózki, deportacje) lub ukryty (władze polityczne wymuszają na grupie etnicznej opuszczenie tego terenu). Bezpośrednią przyczyną jest słabość władzy politycznej większości państwowej na tym terenie, która wynika z braku lojalności, nieposłuszeństwa lub wrogości tej grupy etnicznej (tak to wygląda w ocenie tej większości narodowej) do większości państwowej. 
Kolejnym możliwym modelem relacji większość - mniejszość narodowa lub etniczna jest współpraca z konieczności. Taki stan relacji pojawia się, gdy większość narodowa dojdzie do wniosku, że współpraca ta przyniesie określone korzyści dla niej, co będzie przemawiało za takim rozwiązaniem. Jednak zanim to nastąpi, większość dokona oceny, czy ta współpraca z konieczności wzmocni mniejszość narodową lub etniczną. W przypadku silnego wzmocnienia mniejszości na skutek współpracy większość może nie podjąć takich działań (nie wybrać tego modelu wspólistnienia), gdyż nie jest zainteresowana wzmocnieniem mniejszości z powodu jej notorycznego dążenia do dominacji w swym kraju. Dlatego też taka współpraca jest bardzo trudna.

Następnym rozwiązaniem jest model integracji mniejszości narodowej i etnicznej do państwa narodowego. Ma to na celu włączenie mniejszości narodowych i etnicznych do cywilizacyjnego systemu państwowego, gdzie jest większościowa grupa narodowa, przy czym każda z nich zachowa swą tożsamość i identyfikację. Nie jest to łatwe, bo mechanizm ten (tzw. państwa narodowego) powinien dalej dobrze funkcjonować, tak jak przed integracją mniejszości narodowej lub etnicznej. Jest to pewien model współistnienia, do jakiego dążą mniejszości narodowe i etniczne, gdyż zapewnia im zachowanie tożsamości i kultury. Realizację tego zadania utrudniają przyczyny obiektywne, ponieważ większość narodowa zgodzi się na taki krok (integrację, co oznacza zaniechanie asymilacji) tylko wtedy, kiedy dojdzie do wniosku, że asymilacja mniejszości jest trudna do zrealizowania lub wręcz niemożliwa. Zanim to nastąpi, będzie czyniła próby rozwiązania tej sytuacji za pomocą asymilacji, co będzie wywoływało napięcia i przesilenia. Doprowadzą one do negatywnych skutków na arenie międzynarodowej, pogorszenia się stosunków międzypaństwowych i utrudnienia współpracy między państwami, a nawet do pojawienia się konfliktów. $\mathrm{O}$ wiele lepszym rozwiązaniem jest znalezienie sposobu na integrację mniejszości narodowych i etnicznych w struktury państwa narodowego, co pozwoli uniknąć tych niebezpieczeństw³.

\section{Podłoże historyczne problemu mniejszości narodowych i etnicznych - Polska i Litwa w okresie międzywojennym}

Pierwszym prawnym systemem zbudowania modelu wspólistnienia mniejszości narodowej i większości państwowej był traktat mniejszościowy podpisany po I wojnie światowej. W dniu 28 czerwca 1919 r. Polska podpisała go jako pierw-

${ }^{3}$ Szerzej na ten temat zob.: J. Wołkonowski, Relacje większości i mniejszości w państwie narodowym w XX stuleciu na przyktadzie krajów battyckich. Zarys problematyki, „Rocznik Stowarzyszenia Naukowców Polaków Litwy" [Wilno] 2005, t. 4, s. 6-7. 
sza. Zobowiązywał on ją do przyznania obywatelstwa, ochrony życia i własności mniejszościom narodowym i etnicznym ${ }^{4}$. Oprócz Polski podobne traktaty mniejszościowe podpisały: Czechosłowacja, Jugosławia, Rumunia, Grecja i Armenia. Deklaracje o przestrzeganiu ww. zasad złożyły: Albania, Finlandia, Estonia, Łotwa i Litwa ${ }^{5}$. W przypadku Polski nakładał on szczegółowe zobowiązania wobec mniejszości wywodzących się z dawnych naszych zaborców: Rosjan, Niemców, Austriaków i Węgier. Miało to na celu niedopuszczenie do samosądów czy innych aktów odwetowych ze strony Polaków oraz przyznanie tym osobom pełni praw obywatelskich $^{6}$. Na skutek aktywnej postawy mniejszości żydowskiej na arenie międzynarodowej powyższy traktat zawierał również szczegółowe rozwiązania wobec tej mniejszości idące w kierunku poszanowania tradycji i kultury żydowskiej oraz tolerancji wobec Żydów?

Sejm Rzeczypospolitej w 1924 r. przyjął tzw. ustawy kresowe. Dawały one możliwość mniejszościom terytorialnym - za jakie uznano: białoruską, litewską i ukraińską - używania języków tych mniejszości w relacjach z administracją I i II stopnia, w sądownictwie oraz powołania dwujęzycznych szkół państwowych, gdzie nauczanie odbywało się w dwóch językach - polskim i w języku tej mniejszości. Objęły one swym zasięgiem tylko wschodnie województwa II Rzeczypospolitej oraz dwa powiaty województwa białostockiego (grodzieński i wołkowyski), gdzie były najliczniejsze skupiska tych mniejszości. Uprawnienia dla mniejszości niemieckiej zostały określone w oddzielnych ustawach ${ }^{8}$, zaś prawa mniejszości żydowskiej zawarto w mniejszościowym traktacie, o czym już była mowa wcześniej. Ponadto należy odnotować, że mniejszość żydowską i niemiecką uznano za mniejszości eksterytorialne (nie miały zwartych skupisk zamieszkania jak ludność ukraińska, białoruska czy litewska), dlatego względem nich nie potrafiono znaleźć rozwiązań w ustawach kresowych.

Oddzielną kwestią była autonomia Górnego Śląska, która powstała na mocy konwencji górnośląskiej podpisanej w dniu 15 maja 1922 r. Na podstawie tego

${ }^{4}$ H. Chałupczak, T. Browarek, Mniejszości narodowe w Polsce 1918-1995, Lublin 2000, s. 33-34; J. Ogonowski, Uprawnienia językowe mniejszości narodowych w Rzeczypospolitej Polskiej 1918-1939, Warszawa 2000, s. 42-43.

${ }^{5}$ H. Chałupczak, T. Browarek, Mniejszości narodowe..., s. 33-34; H. Szczerbiński, Rola mniejszości narodowych $w$ kształtowaniu stosunków politycznych $w$ Europie $w$ XX wieku, [w:] Problemy narodowościowe $w$ Europie $i$ ich wplyw na stosunki międzynarodowe na przełomie XX i XXI w., red. H. Szczerbiński, Warszawa 2009, s. 19.

${ }^{6}$ Traktat między Głównymi Mocarstwami Sprzymierzonymi i Stowarzyszonymi a Polską podpisany 28 czerwca 1919 r., Dz. U. 1920, Nr 110, poz. 728, art. 2-9, s. 7-13, http://isap.sejm.gov. pl/DetailsServlet?id=WDU 19201100728 (dostęp: 15.11.2010).

${ }^{7}$ Tamże, art. 9-11, s. 13; J. Ogonowski, Uprawnienia językowe mniejszości narodowych..., s. 43; J. Wołkonowski, Stosunki polsko-żydowskie w Wilnie i na Wileńszczyźnie 1919-1939, Białystok 2004, s. 68-70.

${ }^{8}$ Szerzej na ten temat: J. Ogonowski, Uprawnienia językowe mniejszości narodowych..., s. $116,120-130$. 
aktu prawnego powołano autonomiczne województwo śląskie w granicach Polski i przyznano mu, niemający precedensu, status oraz szerokie prawa dla mniejszości niemieckiej, m. in. obok języka polskiego wprowadzono język niemiecki jako drugi język państwowy. Fakt ten jest uznawany za jeden z najistotniejszych sukcesów w dziejach Ligi Narodów9 .

Większość zapisów pochodzących z traktatu mniejszościowego Polska wniosła do marcowej konstytucji z 1921 r. Gwarantowały one mniejszościom podstawowe prawa obywatelskie ${ }^{10}$. Na mocy 12 artykułu traktatu mniejszościowego osobom należącym do mniejszości pozwolono zwracać się bezpośrednio do Ligi Narodów ${ }^{11}$, co wywołało nieprzerwany strumień skarg wpływających do tego organu. Dnia 13 września 1934 r. minister spraw zagranicznych Polski J. Beck złożył na posiedzeniu Ligi Narodów deklarację o czasowym zawieszeniu przez Polskę tego artykułu traktatu, co zahamowało działalność Ligi w obszarze stosunków mniejszościowych ${ }^{12}$. W praktyce oznaczało to wypowiedzenie przez Polskę 12 artykułu traktatu mniejszościowego, co mogło być traktowane równoznacznie z odrzuceniem przez nią całego traktatu. Takiej deklaracji Rzeczpospolita jednak nie zgłosiła. Należy tu także odnotować, że do kwietniowej konstytucji z 1935 r. wprowadziła podstawowe zapisy traktatu mniejszościowego ${ }^{13}$, zaś ustawy kresowe funkcjonowały do września $1939 \mathrm{r}$.

Litwa, w odróżnieniu od Polski, złożyła tylko deklarację o przestrzeganiu traktatu mniejszościowego. W pierwszych dwóch latach niepodległości (1918-1919) prowadziła ona politykę pragmatyczną wobec swojej największej żydowskiej mniejszości ${ }^{14}$, przyznając jej szerokie prawa, co skutkowało powstaniem kulturowej autonomii mniejszości żydowskiej. Baza ustawodawcza w tej kwestii opierała się na następujących zasadach:

- Żydzi, na równi z innymi obywatelami i narodowościami, korzystali ze wszystkich praw obywatelskich i narodowościowych;

${ }^{9}$ H. Chałupczak, T. Browarek, Mniejszości narodowe..., s. 34-36.

${ }^{10} \mathrm{~J}$. Ogonowski, Uprawnienia językowe mniejszości narodowych ..., s. 46.

${ }^{11}$ Traktat między Głównymi Mocarstwami Sprzymierzonymi i Stowarzyszonymi a Polską podpisany 28 czerwca 1919 r., Dz. U. 1920, Nr 110, poz. 728, art. 12, s. 15.

12 J. Ogonowski, Uprawnienia językowe mniejszości narodowych..., s. 50. Tekst deklaracji z dnia 13 września 1934 r. J. Becka jest następujący: „[...] Poczuwam się do obowiązku oświadczenia już dziś w imieniu rządu polskiego, że do czasu wprowadzenia w życie powszechnego, jednolitego systemu międzynarodowej ochrony praw mniejszości nie będzie on od dnia dzisiejszego współpracował z organami międzynarodowymi w zakresie kontroli nad stosowaniem przez Polskę zasady słusznego i równego traktowania mniejszości”.

${ }^{13} \mathrm{~J}$. Ogonowski, Uprawnienia językowe mniejszości narodowych ..., s. 46.

${ }^{14}$ Według spisu ludności z 1923 r. Litwini stanowili 83,8\% (1 700 tys.), zaś największą mniejszością byli Żydzi - 7,6\% (153,6 tys.) - P. Eberhardt, Przemiany narodowościowe na Litwie, Warszawa 1997, s. 96. 
- mieli proporcjonalne przedstawicielstwo za pomocą swej gminy we wszystkich instytucjach tworzących prawo na Litwie;

- brali udział w instytucjach władzy wykonawczej i sądowej, a dla prowadzenia ich spraw zostało powołane specjalne ministerstwo;

- publicznie korzystali z własnego języka poprzez prasę, teatr, szkołę, a także poprzez tworzenie aktów prawnych o charakterze sądowym i w urzędach publicznych;

- mniejszości żydowskiej zostało zapewnione świętowanie szabasu i innych świąt;

- Żydzi mogli autonomicznie rozwiązywać swe sprawy wewnętrzne dotyczące religii, dobroczynności, pomocy socjalnej, nauczania i kultury duchowej;

- żydowskie gminy lokalne i ich zjazdy zostały ogłoszone jako organy autonomii żydowskiej i otrzymały prawo wydawania uchwał, którym miały podlegać osoby danej narodowości.

Dla żydowskiej autonomii był przyznany status instytucji państwowej. W Sejmie i w samorządach Litwy powstały frakcje żydowskie. Podsumowując, należy odnotować, że lata 1919-1922 są oceniane przez stronę żydowską jako „złoty okres"15.

Tak dalece posunięte prawa dla mniejszości żydowskiej na Litwie miały na celu przekonanie jej do poparcia aspiracji litewskich i opowiedzenia się w kwestii przynależności Wilna jednoznacznie po stronie litewskiej ${ }^{16}$. W 1922 r. autonomia żydowska oraz gminy żydowskie na Litwie zostały zlikwidowane, ponieważ w tym roku sprawa Wilna i Wileńszczyzny została rozwiązana na korzyść Warszawy ${ }^{17}$.

Inaczej sprawa wyglądała z autonomią Kraju Kłajpedzkiego. Wojsko litewskie zbrojnie zajęło ten skrawek ziemi. W konsekwencji takiego postępowania Litwa przegrała sprawę Wilna i na mocy układów międzynarodowych musiała uznać samorząd terytorialny mniejszości niemieckiej w Kraju Kłajpedzkim, gdzie Niemcy stanowili większość. Na mocy konwencji podpisanej przez Litwę 8 maja 1924 r. terytorium Kłajpedy stanowiło jednostkę autonomiczną pod suwerennością Litwy ${ }^{18}$.

W innej, o wiele gorszej, sytuacji znalazła się mniejszość polska na Litwie. Była ona notorycznie nękana przez władze litewskie na skutek trwającego konfliktu o Wilno i braku stosunków dyplomatycznych. Kwestionowano tożsa-

\footnotetext{
15 J. Wołkonowski, Stosunki polsko-żydowskie w Wilnie..., s. 97.

${ }^{16}$ Tamże, s. 98.

${ }^{17}$ Tamże, s. 171; P. Radensky, Žydų reikalų ministeria ir Žydų tautiné autonomia Lietuvoje 1919-1923 metais, [w:] Lietuvos Istorijos Metraštis. 1995 metai, Vilnius 1996, s. 84-97. Więcej na temat autonomii żydowskiej na Litwie zob.: S. Liekis, ,, A State within a State” Jewish autonomy in Lithuania 1918-1925, Vilnius 2003.
}

${ }^{18}$ P. Łossowski, National minorities in the Baltic states 1919-1940, „Acta Polonicae Historica” 1972, nr 25, s. 89. 
mość Polaków, uważając, że są to spolonizowani Litwini, stawiano także duże przeszkody w zakładaniu stowarzyszeń oraz organizowaniu oświaty polskiej ${ }^{19}$. Mimo to na początku $1926 \mathrm{r}$. na Litwie istniały 24 polskie szkoły (dla porównania - w tym okresie było tam 117 szkół żydowskich, 16 niemieckich, 13 rosyjskich i 7 łotewskich). Znajdowały się też 3 gimnazja polskie oraz 14 gimnazjów żydowskich i 1 gimnazjum rosyjskie.

Pewien przełom w życiu politycznym na Litwie nastąpił w 1926 r., kiedy wybory do Sejmu wygrała lewica i rozpoczął się proces demokratyzacji państwa. Liczba polskich szkół w 1926 r. wzrosła z 24 do 78, które skupiały 4089 uczniów. Jednak okres demokratyzacji był krótki, gdyż w grudniu 1926 r. na Litwie dokonano zamachu stanu. Prezydentem został A. Smetona, rozwiązano Sejm, który nie obradował przez następne 8 lat. Odbiło się to negatywnie na sytuacji mniejszości. Już pod koniec 1927 r. na Litwie zostało jedynie 20 szkół polskich (554 uczniów), a w 1937 r. liczba ta zmniejszyła się do 10 szkół (222 uczniów). Pod koniec lat trzydziestych w szkołach z polskim językiem nauczania mogły uczyć się dzieci, których oboje rodzice należeli do narodowości polskiej. Proces nękania szkolnictwa polskiego trwał do ostatnich dni niepodległego państwa litewskiego, kiedy to 14 czerwca 1940 r. minister oświaty Litwy Kazys Jokantas wydał rozporządzenie o zamknięciu 2 ostatnich gimnazjów w Poniewieżu i Wiłkomierzu oraz likwidacji ostatnich 8 polskich szkół podstawowych ${ }^{20}$.

W 1937 r. władze niemieckie wykorzystały autonomię Kraju Kłajpedzkiego i postawiły ultimatum stronie litewskiej, w wyniku którego Litwa utraciła Kraj Kłajpedzki na korzyść III Rzeszy. W marcu 1938 r. Polska wystosowała ultimatum stronie litewskiej w kwestii nawiązania stosunków dyplomatycznych, na które Litwa zareagowała nawiązaniem stosunków.

Druga wojna światowa spowodowała pogorszenie sytuacji mniejszości narodowych w Polsce i na Litwie. Polski rząd na uchodźstwie w latach 1939-1945 stał na stanowisku poszukiwania płaszczyzn porozumienia z mniejszościami narodowymi w kraju w celu włączenia ich do wspólnej walki z najeźdźcą hitlerowskim i sowieckim o przyszłą Polskę. Wymagał od niepodległościowego podziemia polskiego obrony ludności cywilnej bez różnicy na narodowość ${ }^{21}$.

Litwa w okresie II wojny światowej nie potrafiła wyłonić rządu na emigracji, co więcej - większość Litwinów przyjęła w tym czasie opcję proniemiecką. Sytuacja na tym terenie była więc w pełni sterowana przez okupanta niemieckiego, a później sowieckiego. Doszło tu do ogromnego wzrostu napięć w relacjach Litwinów z innymi mniejszościami.

${ }^{19}$ Z. Krajewski, Życie spoleczno-kulturalne Polaków w Republice Litewskiej w latach 1918 1940, „Dzieje Najnowsze” 1996, R. XXXVIII, nr 2, s. 65-66.

${ }^{20}$ K. Buchowski, Polacy w niepodlegtym państwie litewskim, Białystok 1999, s. 287.

${ }^{21}$ J. Wołkonowski, Okręg Wileński Związu Walki Zbrojnej Armii Krajowej w latach 1939 1945, Warszawa 1996, s. 111-113. 


\section{Europejskie modele ochrony praw mniejszości narodowych i etnicznych po II wojnie światowej}

Rada Europy (dalej: RE) powstała w 1949 r. Przez ponad 40 lat poszukiwała skutecznego mechanizmu obrony praw mniejszości narodowych i etnicznych, który powstał w latach dziewięćdziesiątych ubiegłego wieku. Wtedy zbudowano system polityczno-prawny mający zapewnić bezkonfliktowy model współistnienia większości państwowej z mniejszością narodową i etniczną. Wywodzi się on z podstawowych praw człowieka. Do tego systemu wchodzą:

- Konwencja o ochronie praw człowieka i podstawowych wolności;

- Konwencja ramowa o ochronie mniejszości narodowych;

- Europejska karta języków regionalnych lub mniejszościowych;

- akty prawne przyjęte przez państwa na podstawie Konwencji ramowej regulujące prawa mniejszości narodowych i etnicznych;

- międzypaństwowe umowy bilateralne.

Już w pierwszym roku swojego istnienia RE uznała w raporcie Komitetu do spraw Prawnych i Administracyjnych, znaczenie ,problemu szerszej ochrony praw mniejszości narodowych"22.

Rekomendacja 285 (z roku 1961) proponowała następujące sformułowanie tego problemu: „Osobom należącym do mniejszości narodowej nie można odmówić prawa, wespół z innymi członkami ich grup, i na tyle, na ile jest to zgodne z porządkiem publicznym, korzystania z ich własnej kultury, używania własnego języka, zakładania szkół oraz pobierania nauki w języku, który wybiorą lub wyznawania i praktykowania ich własnej religii"23. Dnia 8 września 1993 r. RE doszła do wniosku, że nie ma zgody co do interpretacji terminu „mniejszości narodowe”. Zaś dwa miesiące później - 4 listopada 1993 r., Komitet Ministrów ustanowił Komitet Ad Hoc do spraw Ochrony Mniejszości Narodowych (CAHMIN), który opracował Konwencję ramową o ochronie mniejszości narodowych. Została ona przyjęta podczas 95. Sesji Ministerialnej RE 10 listopada $1994 \mathrm{r}$.

Konwencja ramowa składa się z preambuły i pięciu działów, które nazywane są częścią operacyjną. Dział I (Artykuły 1-3) zawiera postanowienia ustanawiające w ogólny sposób pewne fundamentalne zasady, służące do wyjaśniania innych postanowień Konwencji ramowej. Dział II (Artykuły 4-19) zawiera katalog szczegółowych zasad, zaś Dział III (Artykuły 20-23) - różne postanowienia dotyczące interpretacji i zastosowania Konwencji ramowej. W Dziale IV (Artykuły 24-26) znajdują się postanowienia o nadzorze realizacji Konwencji ramowej, a w Dziale V (Artykuły 27-32) są zawarte klauzule końcowe, które zostały oparte

\footnotetext{
${ }^{22}$ Raport wyjaśniający do Konwencji ramowej Rady Europy o ochronie mniejszości narodowych, http://www.mswia.gov.pl/portal/p1/118/280/Raport_wyjasniajacy_do_Konwencji_ramowej_Rady_ Europy_o_ochronie_mniejszosci_naro.html (dostęp: 30.01.2011).

${ }^{23}$ Tamże.
} 
na modelowych klauzulach końcowych przewidzianych dla konwencji i porozumień zawieranych w ramach $\mathrm{RE}^{24}$.

Podstawowym zagadnieniem tego dokumentu jest status Konwencji ramowej. Oznacza on, że państwa sygnatariusze będą dążyć - każdy swoją drogą - do osiągnięcia celów, jakie stawia Konwencja. Ich realizacja, okres oraz sposób dotarcia do nich w dużym stopniu zależy od relacji większości i mniejszości w tym kraju. Powoduje to, że jedne państwa dość szybko osiągają cele wyznaczone przez Konwencję, a inne zwlekają.

Państwa sygnatariusze zobowiązały się do przyjęcia, tam gdzie to konieczne, odpowiednich środków w celu popierania, we wszystkich sferach życia ekonomicznego, społecznego, politycznego oraz kulturalnego pełnej i rzeczywistej równości między osobami należącymi do mniejszości narodowej a osobami należącymi do większości. Bez uszczerbku dla środków podejmowanych stosownie do ich generalnej polityki integracyjnej, strony mają powstrzymać się od działań lub praktyk mających na celu asymilację oraz zmianę proporcji narodowościowych osób należących do mniejszości narodowych wbrew ich woli. Zobowiązały się także uznać, że każdy należący do mniejszości narodowej ma prawo do używania nazwiska i imion w języku mniejszości oraz ich oficjalnego uznania zgodnie z trybem przyjętym w ich ustawodawstwie.

$\mathrm{Na}$ obszarach zamieszkałych tradycyjnie lub w znaczącej części przez osoby należące do mniejszości narodowej, o ile osoby te tego sobie zażyczą, i tam, gdzie takie życzenie odpowiada ich rzeczywistym potrzebom, państwa sygnatariusze będą starać się zapewnić im, na tyle, na ile to możliwe, warunki, które umożliwią używanie języka mniejszości w stosunkach pomiędzy tymi osobami a organami administracyjnymi oraz umieszczać w języku mniejszości tradycyjne nazwy lokalne, nazwy ulic i inne oznakowania topograficzne o charakterze publicznym, o ile istnieje tam wystarczające zapotrzebowanie na takie oznakowania. W rejonach zamieszkałych tradycyjnie lub przez znaczącą liczbę osób należących do mniejszości narodowych, o ile jest na to wystarczające zapotrzebowanie, strony będą starać się zapewnić osobom należącym do tych mniejszości na tyle, na ile to możliwe, w ramach swoich systemów oświatowych, odpowiednie możliwości uczenia się języka mniejszości lub nauki w tym języku bez uszczerbku dla nauki języka oficjalnego.

Minęło sporo czasu zanim przez RE zostały wypracowane ogólnie przyjęte zasady ustanowienia praw dla mniejszości. W tym celu należało osiągnąć w tej kwestii kompromis, aby większość krajów zrzeszonych w RE respektowało te zasady. Tylko wtedy można było przyjąć Konwencję ramową o ochronie mniejszości narodowych, którą podpisała i ratyfikowała znaczna większość państw należących do RE. To jest znaczący sukces tej inicjatywy. Gorzej jest z realizacją

${ }^{24}$ Konwencja ramowa o ochronie mniejszości narodowych, http://www.mswia.gov.pl/portal/ pl/ 118/278/Konwencja_ramowa_Rady_Europy_o_ochronie_mniejszosci_narodowych.html (dostęp: 30.01.2011). 
samych zasad zawartych w Konwencji, gdyż znaczna część krajów, które podpisały, jak do tej pory, uchyla się od wykonywania zawartych zobowiązań. Ponadto trzeba zaznaczyć, że od czerwca 2006 r. żaden nowy kraj nie przystąpił do Konwencji. Warto też wskazać na dwie grupy krajów, liczące razem osiem państw, z których połowa nie podpisała, a druga połowa podpisała, lecz ma trudności $\mathrm{z}$ ratyfikacją tego aktu prawnego.

Lista państw, które stały się stronami Konwencji (chronologicznie):

Chorwacja, 1.02.1998

Cypr, 1.02.1998

Dania, 1.02.1998

Estonia, 1.02.1998

Finlandia, 1.02.1998

Macedonia, 1.02.1998

Mołdowa, 1.02.1998

Niemcy, 1.02.1998

Hiszpania, 1.02.1998

Rumunia, 1.02.1998

Słowacja, 1.02.1998

San Marino, 1.02.1998

Szwajcaria, 1.02.1998

Węgry, 1.02.1998

Włochy, 1.03.1998

Lichtenstein, 1.03.1998

Czeska Republika, 1.04.1998

Wielka Brytania, 1.05.1998

Ukraina, 1.05.1998

Malta, 1.06.1998

\author{
Austria, 1.07.1998 \\ Słowenia, 1.07.1998 \\ Armenia, 1.11.1998 \\ Rosja, 1.12.1998 \\ Norwegia, 1.07.1999 \\ Bułgaria, 1.09.1999 \\ Irlandia, 1.09.1999 \\ Albania, 1.01.2000 \\ Bośnia i Hercegowina, 1.06.2000 \\ Szwecja, 1.06.2000 \\ Litwa, 1.07.2000 \\ Azerbejdżan, 1.10.2000 \\ Polska, 1.04.2001 \\ Serbia, 1.09.2001 \\ Portugalia, 1.09.2002 \\ Holandia, 1.06.2005 \\ Łotwa, 1.10.2005 \\ Gruzja, 1.04.2006 \\ Czarnogóra, 6.06.2006
}

\section{Lista państw, które nie ratyfikowały Konwencji:}

Belgia (podpisała, nie ratyfikowała)

Grecja (podpisała, nie ratyfikowała)

Islandia (podpisała, nie ratyfikowała)

Luksemburg (podpisał, nie ratyfikował)

Lista państw, które nie są sygnatariuszami:

Andora (nie podpisała, nie ratyfikowała)

Francja (nie podpisała, nie ratyfikowała)

Monako (nie podpisało, nie ratyfikowało)

Turcja (nie podpisała, nie ratyfikowała) ${ }^{25}$

$25 \mathrm{http}: / /$ conventions.coe.int/Treaty/Commun/ChercheSig.asp?NT=157\&CM=\&DF=\&CL $=\mathrm{ENG}$ (dostęp: 30.01.2011). 
Drugim podstawowym dokumentem wchodzącym w system ochrony mniejszości narodowych i etnicznych w Europie jest Europejska karta języków regionalnych lub mniejszościowych. Dotyczy praw językowych przyjętych w ramach RE. Kartę podpisały do tej pory 33 państwa, z czego 24 zakończyły proces ratyfikacji. Polska podpisała ją w dniu 12 maja 2003 r., ratyfikowała 12 lutego 2009 r., a 1 czerwca 2009 r. weszła ona w życie. Europejskiej karty języków regionalnych lub mniejszościowych nie podpisała Litwa, nie podała sygnału o takim zamiarze i nic nie wskazuje na to, iż ma takie plany.

Karta zawiera katalog środków promujących języki regionalne i mniejszościowe w życiu publicznym, w tym w szczególności w zakresie: szkolnictwa, działalności kulturalnej, pisowni imion i nazwisk, programów radiowych i telewizyjnych, dokumentów prawnych, nazw miejscowości oraz używania języków w urzędach.

Zapisy Europejskiej karty języków regionalnych lub mniejszościowych nie nakładają na państwo, które ją przyjmie, wymogu akceptacji całego dokumentu. Każdy z krajów jest natomiast zobowiązany do zastosowania co najmniej trzydziestu pięciu ustępów bądź punktów, wybranych spośród postanowień części III, jednak wymagane jest przyjęcie określonej liczby ustępów bądź punktów z każdego artykułu tej części.

Tabela 1

Lista państw, które podpisały, ratyfikowały i wdrożyły

Europejską kartę języków regionalnych lub mniejszościowych

\begin{tabular}{|c|c|c|c|}
\hline Państwo & Data podpisania & Data ratyfikacji & $\begin{array}{c}\text { Data wejścia } \\
\text { w życie }\end{array}$ \\
\hline 1 & 2 & 3 & 4 \\
\hline Armenia & 11.05 .2001 & 25.01 .2002 & 1.05 .2002 \\
\hline Austria & 5.11 .1992 & 28.06 .2001 & 1.10 .2001 \\
\hline Azerbejdżan & 21.12 .2001 & & \\
\hline Bośnia & 7.09 .2005 & & 1.03 .1998 \\
\hline i Hercegowina & 5.11 .1997 & 5.11 .1997 & 1.12 .2002 \\
\hline Chorwacja & 12.11 .1992 & 26.08 .2002 & 1.01 .2001 \\
\hline Cypr & 9.11 .2000 & 15.11 .2006 & 1.03 .1998 \\
\hline Republika Czeska & 5.11 .1992 & 8.09 .2000 & \\
\hline Dania & 5.11 .1992 & 9.11 .1994 & 1.01 .1999 \\
\hline Finlandia & 7.05 .1999 & & 16.09 .1998 \\
\hline Francja & 5.11 .1992 & & \\
\hline Niemcy & & & \\
\hline
\end{tabular}


Tabela 1 (cd.)

\begin{tabular}{|c|c|c|c|}
\hline 1 & 2 & 3 & 4 \\
\hline Węgry & 5.11 .1992 & 26.04.1995 & 1.03 .1998 \\
\hline Islandia & 7.05 .1999 & & \\
\hline Italia & 27.06 .2000 & & \\
\hline Liechtenstein & 5.11 .1992 & 18.11.1997 & 1.03 .1998 \\
\hline Luksemburg & 5.11 .1992 & 22.06 .2005 & 1.10 .2005 \\
\hline Malta & 5.11 .1992 & & \\
\hline Mołdawia & 11.07 .2002 & & \\
\hline Czarnogóra & 22.03 .2005 & 15.02 .2006 & 6.06 .2006 \\
\hline Holandia & 5.11 .1992 & 2.05 .1996 & 1.03 .1998 \\
\hline Norwegia & 5.11 .1992 & 10.11 .1993 & 1.03 .1998 \\
\hline Polska & 12.05 .2003 & 12.02. 2009 & 1.06 .2009 \\
\hline Rumunia & 17.07.1995 & 29.01 .2008 & 1.05 .2008 \\
\hline Rosja & 10.05 .2001 & & \\
\hline Serbia & 22.03 .2005 & 15.02 .2006 & 1.06 .2006 \\
\hline Słowacja & 20.02 .2001 & 5.09 .2001 & 1.01 .2002 \\
\hline Słowenia & 3.07 .1997 & 4.10 .2000 & 1.01 .2001 \\
\hline Hiszpania & 5.11 .1992 & 9.04 .2001 & 1.08 .2001 \\
\hline Szwecja & 9.02 .2000 & 9.02 .2000 & 1.06 .2000 \\
\hline Szwajcaria & 8.10 .1993 & 23.12 .1997 & 1.04 .1998 \\
\hline Macedonia & 25.07 .1996 & & \\
\hline Ukraina & 2.05 .1996 & 19.09.2005 & 1.01 .2006 \\
\hline Wielka Brytania & 2.03 .2000 & 27.03.2001 & 1.07.2001 \\
\hline
\end{tabular}

Źródło: http://conventions.coe.int/Treaty/Commun/ChercheSig.asp?NT=148\&CM=8\&DF= 30/01/2011\&CL=ENG (dostęp: 30.01.2011).

Jak widać z tabeli 1 spośród 47 państw RE podpisały Europejską kartę 33 państwa, zaś ratyfikowało i wdrożyło - 25. Polska doprowadziła do pomyślnego zakończenia ratyfikacyjnego procesu i jest 25 państwem, które wdrożyło jej zasady.

Kończąc omawianie podstawowych dokumentów dotyczących ochrony praw mniejszości narodowych i etnicznych w Europie, trzeba odnotować, że na tym kontynencie powstała też grupa państw, dla której powyższe standardy na razie są nie do przyjęcia. Najbliższy czas pokaże, czy w tej materii sytuacja ulegnie poprawie. 


\section{Europejskie standardy ochrony mniejszości narodowych i etnicznych w Polsce}

Polska dokonała dużych zmian w kierunku wypełnienia podjętych zobowiązań wynikających z Konwencji ramowej o ochronie mniejszości narodowych i Europejskiej karty języków regionalnych lub mniejszościowych. Dnia 6 stycznia 2005 r. została przyjęta ustawa o mniejszościach narodowych i etnicznych oraz o języku regionalnym ${ }^{26}$. Określono w niej, że w Polsce za mniejszości narodowe uznaje się następujące: białoruską, czeską, litewską, niemiecką, ormiańską, rosyjską, słowacką, ukraińską, żydowską. Za mniejszości etniczne uznano mniejszość karaimską, łemkowską, romską i tatarską, zaś językiem regionalnym uznano język kaszubski.

Zgodnie z ustawą o mniejszościach narodowych i etnicznych gminy, w których osoby należące do mniejszości zarówno narodowej, jak i etnicznej lub posługujące się językiem regionalnym stanowią co najmniej 20\% mieszkańców, mogą wprowadzić język mniejszości jako język pomocniczy stosowany w kontaktach z organami gminy oraz w postępowaniu sądowym pierwszej instancji. Ogółem na terenie Rzeczypospolitej liczba takich gmin wynosi obecnie 51 z ogólnokrajowej liczby - 2479 gmin. Obecnie tylko 4 mniejszości stanowią nie mniej niż 20\% mieszkańców gmin. Są to następujące mniejszości:

- białoruska (język pomocniczy wprowadzono w 5 gminach z 12);

- litewska (język pomocniczy wprowadzono w 1 gminie z 1);

- niemiecka (język pomocniczy wprowadzono w 22 gminach z 28);

- kaszubska (język pomocniczy wprowadzono w 2 gminach z 10) ${ }^{27}$.

Tabela 2

Lista gmin wpisanych na podstawie art. 10 ustawy z 6 stycznia 2005 r. o mniejszościach narodowych i etnicznych oraz o języku regionalnym do Urzędowego Rejestru Gmin, w których jest używany język pomocniczy

\begin{tabular}{|c|c|c|c|c|}
\hline Nazwa gminy & Powiat & Województwo & $\begin{array}{c}\text { Język } \\
\text { pomocniczy }\end{array}$ & Data wpisu \\
\hline 1 & 2 & 3 & 4 & 5 \\
\hline Radłów & oleski & opolskie & niemiecki & 25.01 .2006 \\
\hline Chrząstowice & oleski & opolskie & niemiecki & 25.01 .2006 \\
\hline Izbicko & strzelecki & opolskie & niemiecki & 6.03 .2006 \\
\hline Biała & prudnicki & opolskie & niemiecki & 6.03 .2006 \\
\hline Walce & krapkowicki & opolskie & niemiecki & 4.04 .2006 \\
\hline Strzeleczki & krapkowicki & opolskie & niemiecki & 17.05 .2006 \\
\hline Leśnica & strzelecki & opolskie & niemiecki & 17.06 .2006 \\
\hline
\end{tabular}

${ }^{26}$ Dz. U. 2005, Nr 17, poz. 141.

${ }^{27}$ http://www.mswia.gov.pl/ftp/pdf/mn_wykaz_gmin.pdf (dostęp: 30.01.2011). 
Tabela 2 (cd.)

\begin{tabular}{|c|c|c|c|c|}
\hline 1 & 2 & 3 & 4 & 5 \\
\hline Puńsk & sejneński & podlaskie & litewski & 25.05 .2006 \\
\hline Prószków & opolski & opolskie & niemiecki & 11.07 .2006 \\
\hline Parchowo & bytowski & pomorskie & kaszubski & 16.08.2006 \\
\hline Jemielnica & strzelecki & opolskie & niemiecki & 28.08 .2006 \\
\hline Ujazd & strzelecki & opolskie & niemiecki & 28.08 .2006 \\
\hline Kolonowskie & strzelecki & opolskie & niemiecki & 22.09.2006 \\
\hline $\begin{array}{l}\text { Lasowice } \\
\text { Wielkie }\end{array}$ & kluczborski & opolskie & niemiecki & 18.10 .2006 \\
\hline Reńska Wieś & $\begin{array}{c}\text { kędzierzyńsko- } \\
\text {-kozielski }\end{array}$ & opolskie & niemiecki & 26.10 .2006 \\
\hline Tarnów Opolski & opolski & opolskie & niemiecki & 15.02 .2007 \\
\hline Bierawa & $\begin{array}{c}\text { kędzierzyńsko- } \\
\text {-kozielski }\end{array}$ & opolskie & niemiecki & 23.04 .2007 \\
\hline Zębowice & oleski & opolskie & niemiecki & 23.10 .2007 \\
\hline Sierakowice & kartuski & pomorskie & kaszubski & 23.10 .2007 \\
\hline $\begin{array}{l}\text { Hajnówka } \\
\text { miasto }\end{array}$ & hajnowski & podlaskie & białoruski & 3.12 .2007 \\
\hline Turawa & opolski & opolskie & niemiecki & 12.09 .2008 \\
\hline Murów & opolski & opolskie & niemiecki & 22.04 .2009 \\
\hline Dobrzeń Wielki & opolski & opolskie & niemiecki & 22.04 .2009 \\
\hline Głogówek & prudnicki & opolskie & niemiecki & 22.04 .2009 \\
\hline Orla & bielski & podlaskie & białoruski & 7.05.2009 \\
\hline Dobrodzień & oleski & opolskie & niemiecki & 13.05.2009 \\
\hline Kompachcice & opolskie & opolskie & niemiecki & 4.06.2009 \\
\hline Narewka & hajnowski & podlaskie & białoruski & 16.06 .2009 \\
\hline Czyże & hajnowski & podlaskie & białoruski & 10.02 .2010 \\
\hline Hajnówka & hajnowski & podlaskie & białoruski & 28.05 .2010 \\
\hline
\end{tabular}

Źródło: http://bip.mswia.gov.pl/portal/bip/13/71/Rejestry.html (dostęp: 29.06.2010).

Ustawa pozwala również na wprowadzenie podwójnego nazewnictwa ulic i miejscowości. Ogółem wprowadzono podwójne nazewnictwo w 39 gminach dla 740 miejscowości, z których 310 to nazwy niemieckie, 374 - kaszubskie, 30 - litewskie, 25 - białoruskie i 1 nazwa w języku łemkowskim ${ }^{28}$.

${ }^{28} \mathrm{http}: / /$ bip.mswia.gov.pl/portal/bip/13/71/Rejestry.html (dostęp: 30.01.2011). 
Od 2005 r. osoby należące do mniejszości narodowych lub etnicznych, których alfabet opiera się na alfabecie łacińskim, mogą wpisać w dokumentach państwowych imię i nazwisko w języku mniejszości ${ }^{29}$. RE dokonuje okresowego monitorowania w okresie pięcioletnim w kwestii realizacji podjętych zobowiązań. Polska wypadła pozytywnie podczas monitorowania przez ekspertów RE w latach 2002-2003 i 2007-2009. Odnotowano wiele pozytywnych rozwiązań i stwierdzono duży postęp w realizacji wyżej wymienionych postanowień ${ }^{30}$.

Eksperci przedstawili swe propozycje i kilka zastrzeżeń w następujących kwestiach:

„Prawo używania «języka pomocniczego»w administracji jest ograniczone do samorządowych władz gminnych i nie jest rozszerzone na policję, służbę zdrowia, urzędy pocztowe lub administrację państwową na szczeblu lokalnym”.

„Brak odpowiedniej reprezentacji politycznej mniejszości narodowych i etnicznych".

„Brak decyzji w sprawie mniejszości śląskiej” ${ }_{31}$.

Można zatem wyciągnąć wniosek, że ostateczna rezolucja RE z drugiego monitoringu (2007-2009) będzie jednoznacznie pozytywna.

\section{Europejskie standardy ochrony mniejszości narodowych i etnicznych na Litwie}

Litwa w odróżnieniu od Polski miała już w latach dziewięćdziesiątych ustawę o mniejszościach narodowych, która była przyjęta jeszcze za czasów sowieckich w 1989 r. ${ }^{32}$, zaś w 1991 r. została nieznacznie znowelizowana i przyjęta przez

\footnotetext{
${ }^{29}$ Komitet Doradczy Konwencji ramowej o ochronie mniejszości narodowych, druga opinia dotycząca Polski, przyjęta w dniu 20 marca 2009 r., s. 30; http://www.coe.int/t/dghl/monitoring/ minorities/3 FCNMdocs/PDF 2nd OP Poland pl.pdf (dostęp: 30.01.2011).

30 Tamże, s. 44. W Raporcie odnotowano: „216. Przyjęcie Ustawy o mniejszościach narodowych i etnicznych oraz o języku regionalnym w styczniu 2005 r. jest faktem, który należy docenić. [...] 217. Jeśli chodzi o praktykę, stosunki pomiędzy mniejszościami narodowymi a ogółem społeczeństwa charakteryzuje atmosfera wzajemnego zrozumienia i tolerancji. Instytucje publiczne, takie jak Rzecznik Praw Obywatelskich i Pełnomocnik Rządu do spraw Równego Traktowania, przyjęły aktywną postawę i kontynuowały wysiłki zmierzające do propagowania poszanowania praw człowieka i kulturowej różnorodności w Polsce. 218. W ciągu ostatnich kilku lat, Polska stworzyła szereg programów i zastosowała wiele środków mających na celu zmniejszenie trudności, z którymi styka się społeczność romska w zakresie mieszkalnictwa, zatrudnienia i opieki zdrowotnej, dostarczając rozwiązań problemów, z którymi stykają się w dziedzinie edukacji oraz bardziej ogólnie, zwalczaniu ich wyłączenia społecznego i marginalizacji”.

${ }^{31} \mathrm{http}: / /$ www.coe.int/t/dghl/monitoring/minorities/3_FCNMdocs/Table_en.asp\#Poland; szerzej na temat zaleceń: http://www.coe.int/t/dghl/monitoring/minorities/3_FCNMdocs/PDF_2nd_OP_ Poland_pl.pdf (dostęp: 30.01.2011), s. 46-47.

${ }^{32} \mathrm{http}: / / \mathrm{www} 3.1 \mathrm{rs} .1 \mathrm{t} / \mathrm{pls} / \mathrm{inter} 3 /$ dokpaieska.showdoc_1?p_id=18856\&p_query=\&p_tr2= (dostęp: 30.01.2011).
} 
Sejm już niepodległej Litwy ${ }^{33}$. Liczyła ona 10 krótkich artykułów i pozwalała na podwójne nazewnictwo, wprowadzenie języka pomocniczego oraz zakładanie filii wyższych uczelni na potrzeby kształcenia mniejszości narodowych. $\mathrm{Na}$ początku 2010 r. wygasł okres funkcjonowania tej ustawy i przygotowano nowy projekt. Przewiduje on również wprowadzenie języka pomocniczego w jednostkach zwarcie zamieszkałych przez mniejszości narodowe, podwójne nazewnictwo oraz zakładanie filii wyższych uczelni na potrzeby kształcenia mniejszości narodowych ${ }^{34}$. Pierwsze czytanie nowej ustawy odbyło się wiosną 2010 r., ale do końca roku nie została jednak przyjęta. W tej sytuacji mniejszości narodowe i etniczne na Litwie pozostały bez jednego z podstawowych aktów prawnych.

Obecnie na Litwie brak jest rozwiązań dotyczących wprowadzenia języka pomocniczego oraz podwójnego nazewnictwa. Nie ma w tej kwestii ustawy o mniejszościach narodowych oraz aktów wykonawczych (nie były one przyjęte i podczas działania poprzedniej ustawy o mniejszościach). Skład narodowościowy na Litwie jest mocno zróżnicowany, gdyż w dwóch rejonach (z 50) polska mniejszość w tym kraju stanowi ponad połowę mieszkańców - w solecznickim $82 \%$ ogółu, zaś w wileńskim ponad $60 \%$. Kiedy w lipcu 2000 r. Litwa podpisała, a później ratyfikowała i wdrożyła ramową Konwencję o ochronie mniejszości, w jednostkach tych rozpoczął się ruch na rzecz wdrożenia zasad danej Konwencji. Mieszkańcy zaczęli spontanicznie domagać się wprowadzenia polskiego języka pomocniczego, dwujęzycznego nazewnictwa litewsko-polskiego miejscowości oraz pisowni imion i nazwisk w wersji polskiej. Ruch ten nabrał dodatkowego impetu po tym, jak w Polsce po 2005 r. kwestie te zostały rozwiązane pozytywnie dla litewskiej mniejszości. Władze litewskie przez ostatnie 15 lat wielokrotnie składały różnego rodzaju deklaracje zapewniające, że te problemy będą pozytywnie rozwiązane w duchu europejskich standardów. Niestety tak się nie stało. W ostatnich latach w związku ze zwlekaniem rozpatrzenia tej sprawy ludność polska zaczęła spontanicznie i samodzielnie wprowadzać język pomocniczy oraz podwójne nazewnictwo, zaś temat pisowni polskich imion i nazwisk stał się tematem wielu rozmów dla najwyższej rangi polityków Litwy i Polski. Żadnego z tych problemów do dzisiaj nie rozwiązano. Co więcej, władze Litwy przystąpiły do zdejmowania tablic w języku polskim i administracyjnego karania inicjatorów. Przedstawiciel rządu RL na powiat wileński Jurgis Jurkevičius zwrócił się do sądu o usunięcie nazewnictwa polskiego na tablicach ulic. Sąd nakazał usunięcie polskojęzycznych nazw ulic, motywując tym, że Konwencja ramowa o ochronie mniejszości ma „ogólnikowy charakter”. Brak ustawy o mniejszościach narodowych oraz aktów wykonawczych powoduje takie reperkusje ze strony urzędników litewskich. Obecnie władze Litwy zasłaniają się ustawą o języku państwowym,

${ }^{33} \mathrm{http} / / / \mathrm{www} 3.1 \mathrm{rs} .1 \mathrm{lt} / \mathrm{pls} /$ inter3/dokpaieska.showdoc_1?p_id=22150\&p_query=\&p_tr2= (dostęp: 30.01.2011).

${ }^{34} \mathrm{http}: / / \mathrm{www} 3.1 r s .1 \mathrm{t} / \mathrm{pls} / \mathrm{inter} 3 /$ dokpaieska.showdoc_l?p_id=363451\&p_query=\&p_tr2 $=($ dostęp: $30.01 .2011)$. 
która nie przewiduje takich dwujęzycznych rozwiązań ${ }^{35}$. Artykuł 17 tej ustawy głosi: „Napisy publiczne w Republice Litewskiej są w języku państwowym”. Kolejny artykuł 18 stwierdza: „Nazwy organizacji wspólnot narodowych, ich napisy informacyjne obok języka państwowego mogą być podane także w innych językach. Format napisów w innych językach nie może być większy od formatu napisów w języku państwowym"36. Z jednej strony ustawa o mniejszościach narodowych w okresie 1990-2010 (gdy obowiązywała) zezwalała na dwujęzyczne nazewnictwo i wprowadzenie języka pomocniczego, zaś z drugiej - ustawa o języku państwowym takich rozwiązań nie przewidywała. Sądy litewskie wskazywały na ustawę o języku państwowym jako na akt większej wagi, co decydowało o przyjęciu wyroków zgodnych z ustawą o języku państwowym ${ }^{37}$. To są tak zwane „krzyżowe rozwiązania”, za pomocą których władze litewskie świadomie wprowadzały w błąd opinię międzynarodową i swoje mniejszości. Przyczyną takiego stanu rzeczy jest obawa władzy litewskiej o utratę dominacji na tych terenach. Dodatkowo trzeba zauważyć, że nie ma w ustawodawstwie litewskim aktów wykonawczych (i technicznych), w jaki sposób można było zamieścić dwujęzyczne nazwy ulic, na co wskazywali niejednokrotnie eksperci RE.

Rozbieżność, jaka powstała między ratyfikowaną Konwencją ramową o ochronie mniejszości narodowych a stanem prawnym, utworzonym przez władze litewskie, zauważyli eksperci RE podczas monitoringu. Dnia 21 lutego 2003 r. Komitet Doradczy RE wyrażał niezadowolenie z powodu przygotowanego przez litewskie instytucje rządzące sprawozdania państwowego bez narady z przedstawicielami mniejszości narodowych oraz dlatego, że sprawozdanie to przedstawiono mniejszościom narodowym dopiero po przedłożeniu go $\mathrm{RE}^{38}$.

W kolejnym punkcie opinii stwierdzono, że „Komitet Doradczy akcentuje brak pewnej konsekwencji w obowiązujących przepisach aktów prawnych oraz w przedłożonych mu projektach o ochronie mniejszości narodowych. Na podstawie informacji uzyskanej od kilku osób, z którymi były prowadzone rozmowy, Komitet Doradczy oświadcza, iż brak jest konsekwencji w realizacji poszczególnych aspektów Konwencji ramowej. Nawiązując do powyższego, Komitet Doradczy wyraża żal, iż nie doszło do spotkania z przedstawicielami Ministerstwa Sprawiedliwości, którzy potrafiliby udzielić korzystnych wyjaśnień na temat prowadzonych procesów prawnych"39. Dalej eksperci uznali, że w obowiązujących litewskich aktach prawnych brakuje prawnego określenia „,wspólnoty narodowej”

${ }^{35}$ Ustawa o języku państwowym z 31 stycznia 1995 r., Nr 1-779, http://www3.lrslt/pls/ inter3/ dokpaieska.showdoc_1?p_id=15211\&p_query=Valstybin $\%$ EBs $\% 20$ kalbos $\% 20 \%$ E1 statymas\&p_ tr2=2 (dostęp: 30.01 .2011$)$.

${ }^{36}$ Tamże.

${ }^{37}$ Komitet Doradczy o stosowaniu Konwencji ramowej ochrony mniejszości narodowych. Opinia o Litwie, http://www.coe.int/t/dghl/monitoring/minorities/3_FCNMdocs/PDF_1st_OP_Lithuania_ pl.pdf (dostęp: 30.01.2011), p. 58, s. 17.

${ }^{38}$ Tamże, p. 8, s. 5.

${ }^{39}$ Tamże, p. 9, s. 5. 
oraz wyjaśnienia, jakie grupy narodowe Litwa uważa za chronione Konwencją ramową ${ }^{40}$.

Komitet Doradczy RE odnotował, że parlament Litwy rozważał przyjęcie określenia, co to jest mniejszość narodowa, w takich definicjach: „Grupa osób mieszkających w Republice Litewskiej, którzy podjęli samodzielną decyzję o przynależności do innej narodowości czy grupy etnicznej niż litewska" lub „Osoba, która podjęła samodzielną decyzję o przynależności do mniejszości narodowej lub grupy etnicznej oraz która dąży do zachowania kultury, języka, tradycji, obyczajów oraz tożsamości narodowej i etnicznej tej grupy", jednak uważa je za niewystarczająco precyzyjne ${ }^{41}$.

W kolejnych punktach eksperci RE stwierdzili, że „Osoby należące do mniejszości narodowych żyją w zgodzie z innymi mieszkańcami, ich stosunkom jest charakterystyczna tolerancja, wzajemny szacunek oraz zrozumienie. Jednakże Komitet Doradczy zaznacza, że społeczeństwo litewskie jest wrogo nastawione do niektórych mniejszości narodowych, zwłaszcza do Romów i Żydów"42 oraz „Komitet Doradczy wyraża zaniepokojenie sytuacją, gdy litewscy politycy, zwłaszcza niektórzy członkowie Parlamentu, wypowiadają opinie rasistowskie, ksenofobijne oraz antysemickie. Pomimo że takie wypadki zdarzają się sporadycznie, Komitet Doradczy uważa, że w walce z niniejszym zjawiskiem należy zastosować dodatkowe środki. Według źródeł nierządowych, poszczególne negatywne stereotypy oraz ksenofobijne i antysemickie opinie o mniejszościach narodowych są umieszczane na najczęściej odwiedzanych przez społeczeństwo stronach internetowych oraz w grach telewizyjnych"43.

Odnośnie do języka pomocniczego oraz podwójnego nazewnictwa eksperci RE odnotowali, że ,[...] w ustawie o mniejszościach narodowych brak kryteriów ustalenia takich regionów (gdzie ma być stosowany język pomocniczy i podwójne nazewnictwo - przyp. J. W.), co pozwala na różne interpretacje"44.

Dalej w raporcie zaznaczono: „Komitet Doradczy wyraża zaniepokojenie pokrzyżowanymi przepisami oraz brakiem dokładnych kryteriów w ustalaniu «regionów, gdzie większość stanowią mniejszości narodowe». Komitet Doradczy zachęca instytucje rządzące do podjęcia niezbędnych środków w celu usunięcia niejasności prawnych w tej sprawie $[\ldots]]^{\prime 45}$.

W kwestii pisowni imion i nazwisk stwierdzono: „Komitet Doradczy wyraża żal, że bez względu na dyskusje prowadzone przez kilka lat na poziomie narodowym oraz w ramach dwustronnych stosunków, nie zatwierdzono przychylnej dla

\footnotetext{
${ }^{40}$ Tamże, p. 18, s. 7.

${ }^{41}$ Tamże, p. 23, 24, s. 8-9.

${ }^{42}$ Tamże, p. 42, s. 13.

${ }^{43}$ Tamże, p. 43, s. 13.

${ }^{44}$ Tamże, p. 54, s. 16.

${ }^{45}$ Tamże, p. 56, s. 16.
} 
wszystkich decyzji o zasadach zapisywania imion i nazwisk mniejszości narodowych (zwłaszcza Polaków) w paszportach"46.

Końcowe wnioski ekspertów RE w opinii wyrażały zaniepokojenie: „Komitet Doradczy zauważył dominującą ostatnio tendencję do obniżenia poziomu ochrony mniejszości narodowych. Niniejsza tendencja została odzwierciedlona w zatwierdzonych oraz proponowanych zmianach do aktów prawnych" ${ }^{47}$. Przejawiło się to w tym, ,że aktywna polityka państwa dotycząca propagowania języka państwowego budzi niepokój niektórych mniejszości narodowych, obawiających się utraty swojej kultury i tożsamości narodowej"48.

W uwagach końcowych eksperci RE stwierdzili, że ,[...] obecne reformy aktów prawnych mogą przyczynić się do ograniczenia poszczególnych praw i swobód mniejszości narodowych. Komitet Doradczy twierdzi, że instytucje rządzące powinny zapewnić, aby powyższe reformy ustawowe nie doprowadziły do zmniejszenia obowiązującego poziomu ochrony mniejszości narodowych. Poza tym, biorąc pod uwagę brak konsekwencji w obowiązujących przepisach prawnych oraz aktach prawnych, należy stworzyć konsekwentne podstawy prawne ochrony mniejszości narodowych. W niniejszej sprawie należy poczynić dodatkowe starania o prawne uregulowanie obecnie niewyraźnie ustalonego prawa używania języka mniejszości narodowych w instytucjach administracyjnych oraz nazwach miejscowości, ulic oraz innych nazwach topograficznych"49.

Przedstawione wyżej rezolucje pochodzą z monitoringu RE, który miał miejsce na Litwie w 2003 r. Obecnie nastąpiło znaczne pogorszenie się sytuacji, gdyż od 1 stycznia 2010 r. nie działa ustawa o mniejszościach narodowych, rozwiązano departament wychodźstwa i mniejszości narodowych, miały miejsce kolejne sądy i kary za podwójne nazewnictwo oraz znacznie pogorszyły się stosunki między Litwą i Polską. Wyniki kolejnego monitoringu RE na Litwie, który miał miejsce w 2008 r., są do tej pory zastrzeżone ${ }^{50}$. Budzi to niepokój oraz duże napięcie na arenie międzynarodowej.

\section{Wnioski}

W latach dziewięćdziesiątych XX w. RE podjęła konkretne pozytywne kroki w celu wprowadzenia międzynarodowej ochrony mniejszości narodowych w postaci Konwencji ramowej ochrony mniejszości narodowych i Europejskiej karty języków regionalnych i mniejszościowych, którą podpisało większość kra-

${ }^{46}$ Tamże, p. 57, s. 17.

${ }^{47}$ Tamże, p. 87, s. 23.

${ }^{48}$ Tamże, p. 95, s. 25.

${ }^{49}$ Tamże, p. 110, s. 28.

${ }^{50} \mathrm{http} / /$ www.coe.int///dghl/monitoring/minorities/3_FCNMdocs/Table_en.asp\#Lithuania (dostęp: 30.01.2011). 
jów Europy. Konwencja ma charakter programowy i ustala pewne cele, do których państwa sygnatariusze mają dążyć. Sposób ich osiągnięcia pozostawiono w gestii decyzyjnej samych krajów. Dobrowolność i różnorodność dróg powoduje słabą skuteczność Konwencji i Europejskiej karty.

Polska i Litwa przyjęly całkowicie odmienne sposoby wywiązywania się ze zobowiązań Konwencji ramowej o ochronie mniejszości narodowych.

Polska w 2005 r. przyjęła ustawę o mniejszościach narodowych i potrafiła wdrożyć podstawowe zasady Konwencji i Europejskiej karty, przyjmując odpowiednie akty wykonawcze. Pozwoliło to na wprowadzenie języka pomocniczego, podwójnego nazewnictwa oraz pisowni imion i nazwisk w języku tych mniejszości.

Konwencja ramowa na Litwie nie znalazła praktycznego wdrożenia z powodu stosowania krzyżowych rozwiązań - ustawa o języku państwowym miała pierwszeństwo przed ustawą o mniejszościach narodowych. Ratyfikowana Konwencja ramowa została oceniona przez sądy na Litwie tylko jako programowa, co oznacza, że nie muszą być spełniane jej założenia. Litwa nie przyjęła Europejskiej karty języków regionalnych i mniejszościowych. Podstawową przyczyną takiego stanu są obawy polityków Litwy dotyczące wzmocnienia polskiej mniejszości i utraty własnej dominacji. 